Research paper

\title{
Evolution of fluid flow and heat distribution over geological time scales at the margin of unconfined and confined carbonate sequences - A numerical investigation based on the Buda Thermal Karst analogue
}

\author{
T. Havril ${ }^{\text {a, }}$, J.W. Molson ${ }^{\text {b }}$, J. Mádl-Szőnyi ${ }^{\text {a }}$ \\ a Department of Physical and Applied Geology, Eötvös Loránd University, Budapest, Hungary \\ ${ }^{\mathrm{b}}$ Department of Geology and Geological Engineering, Laval University, Quebec City, Canada
}

\section{A R T I C L E I N F O}

\section{Article history:}

Received 1 March 2016

Received in revised form

18 August 2016

Accepted 3 October 2016

Available online $\mathrm{xxx}$

\section{Keywords:}

Numerical modelling

Gravity-driven groundwater flow

Thermal convection

Tectonic uplift

Carbonate karst systems

\begin{abstract}
A B S T R A C T
Hydrogeological processes acting at the margins of confined and unconfined thick carbonate sequences are particularly interesting due to a complex system evolution including partial uplift of fully confined carbonate systems and subsequent erosion of cover layers. We provide insights into this evolution by simulating coupled density-dependent fluid flow and heat transport based on the Buda Thermal Karst (BTK) system (Hungary) in a 2D vertical plane. Applying an equivalent porous medium (EPM) approach using the Heatflow-Smoker finite element model, scenario modelling of three evolutionary steps was carried out between the fully-confined carbonate stage through to partly and completely unconfined conditions over the western ridge. The numerical simulations were used to derive the main evolutionary characteristics of groundwater flow and heat transport patterns for the unconfined and confined parts of the hydrogeologic system. The initial fully-confined state led to the development of thermal convection cells due to the insulating role of the low-permeability confining layer, which facilitates buoyancy-driven flow by restricting the dissipation of heat. Over geological time, these cells were gradually overprinted by gravity-driven flow and thermal advection due to uplift of the west ridge. The limited thickness of the cover allowed sufficient water infiltration into the system, which led to increased cooling. Further uplifting led to a prevalence of gravity-driven groundwater flow. The results highlight the critical role of confining formations on flow patterns, and their effect on heat distribution and dissipation over geological time scales. The results have important implications for heat accumulation as well as for the development of a deep geothermal energy potential in confined carbonates.
\end{abstract}

(c) 2016 Elsevier Ltd. All rights reserved.

\section{Introduction and goals of the study}

Deep regional groundwater flow systems are not static - they evolve continuously during the geological history of their host sedimentary basins (Ingebritsen and Sanford, 1999). Transient hydraulic and thermal conditions will evolve, for example, in response to a variety of changes including those related to climate, thermal conditions, sediment compaction, erosion, geochemical reactions, tectonic uplift and stress (Deming, 2002). Understanding the transient history of subsurface fluid flow systems, therefore, could help to explain the role of deep groundwater in a number of geologic processes including diagenesis, hydrothermal flow and ore

\footnotetext{
* Corresponding author.

E-mail address: timihavril@gmail.com (T. Havril).
}

genesis, as well as petroleum migration (Bredehoeft and Norton, 1990), porosity enhancement and hypogene karstification.

Understanding the main hydrogeological processes within thick carbonate deposits is challenging. A particularly interesting situation arises at the margin of confined and unconfined carbonate sequences, which was demonstrated for the steady-state case in the context of the Buda Thermal Karst (BTK) system (Alföldi et al., 1968; Alföldi and Kapolyi, 2007; Zsigmondy, 1878) by Mádl-Szőnyi and Tóth (2015). However, the transient evolution of hydrogeological flow systems from partial uplift of fully confined carbonate systems and subsequent erosion of cover layers has not yet been examined.

This paper aims to address several important groundwater flow and heat transport process-related questions which arise from this geological evolution, namely: i) What are the main effects of lowpermeability confining formations overlying a permeable carbonate system?; ii) What are the main characteristics of the flow field 
and temperature distribution in these carbonate systems with decreasing cover thickness at one ridge?, and iii) What is the relative importance of gravity and buoyancy as driving forces in the different geological evolutionary stages with different confining layer thicknesses?

Insights into deep regional hydrogeological processes can be significantly improved with numerical models, as was shown, for example, by Gleeson and Manning (2008), who defined the salient controls on regional groundwater flow in 3D mountainous terrain by systematically varying topographic and hydrogeologic variables. Cardenas and Jiang (2010) pointed out the importance of depthdependent heterogeneity on groundwater flow, transport, and residence time distributions of subsurface fluids via numerical flow and transport models. Sandeep et al. (2016) highlighted the effect of temporal evolution of permeability and flow fields through several simulations with various combinations of initial permeability as well as with transitional flow regimes in the presence of through-flow with different fluxes.

In the current study, semi-synthetic snapshot models of coupled density-dependent flow and heat transport were used to better understand the paleohydrogeology and thermal history of marginal areas of confined and unconfined carbonate sequences within the context of the Buda Thermal Karst system. Based on these snapshot simulations, we follow the effects of changing conditions on the fluid-potential and heat distribution during the geological evolution of the basin. Effects of transient flow evolution on geochemistry and permeability in carbonate basins can then be interpreted based on these results.

\section{Analogue area}

The Buda Thermal Karst system in Hungary is considered an analogue pilot area for numerical studies since it is situated at the margin of unconfined and confined carbonate systems. A simplified geological and hydrogeological conceptual model of this system can be used to provide realistic hydrogeological conditions and parameters for the numerical study.

Globally, this hydrogeological situation is not unique as many other systems are also characterized by similar geological settings, for example the Upper Floridan aquifer system in west-central Florida, USA (Gulley et al., 2014), the Jinan karst aquifer system in east China (Wang et al., 2015), the Frasassi Anticline on the eastern slope of the Apennine mountain chain in Italy (Galdenzi et al., 2008), as well as the Black Hills in South Dakota, USA (Palmer and Palmer, 2000).

The BTK is an active karst system, where extensive geological, speleological and hydrogeological information is available. It is located at the north-eastern margin of the Transdanubian Range (TR) in Hungary, in the central part of the Pannonian Basin. The Mesozoic carbonate suite of the TR (Haas, 1988) is downfaulted and continues deep on the basin side (Pest plain) to the east of the Danube River, under a thick Neogene siliciclastic sedimentary cover (Fig. 1). Under the Pest plain these confined carbonates are suitable for geothermal development (Mádl-Szőnyi et al., 2015), and some areas also contain hydrocarbon reservoirs (e.g. Milota et al., 1995). Several studies have been made in order to gain insight into the recent hydrogeological system (Eröss et al., 2008, 2012) and to understand the paleo-fluid migration processes (Poros et al., 2012). Hydraulic studies have identified gravity as the main driving force of the system (Erhardt et al., 2013) while buoyancy due to thermal gradients and permeability conditions can also be important. The base level of erosion is the Danube River.

From the Late Miocene, inversion of the Pannonian Basin contributed to the uplift of certain blocks (Horváth et al., 1988), including the Buda Hills as part of the Transdanubian Range. East of the Danube, uplift of the Gödöllő Hills Region started somewhat later and has been ongoing for the past 4 million years (RuszkiczayRüdiger et al., 2006, 2007). During this uplifting, a watershed east of the Danube developed, which defines the eastern boundary of the BTK (Mádl-Szönyi et al., 2015). Due to the thinned lithosphere below this basin, the entire area is characterized, even today, by an elevated heat flux (an average of $100 \mathrm{mWm}^{-2}$ ) (Lenkey et al., 2002).

Beginning in the Miocene, meteoric fluid has infiltrated the western part of the system as this area became subaerially exposed due to the partial erosion of the Paleogene sequence. Poros et al. (2012) estimated that $800 \mathrm{~m}$ of sediments have been eroded since the late Early Miocene based on measured entrapment temperatures and pressures of fluid inclusions in calcite veins. The contribution of basinal fluids from the Pest plain east of the Danube to the Buda Karst was raised by Alföldi (1981) and later identified by Erőss (2010) as well as in the diagenetic study of Poros et al. (2012). Vertical leakage of basinal fluids across the confining layer east of the BTK was first proposed by Mádl-Szőnyi and Tóth (2015).

\section{Simulation approach}

Characteristic patterns of groundwater flow and thermal energy transport at the margin of the unconfined and confined carbonate region were generated using numerical simulations. We consider different thicknesses of the cover formation during three distinct evolutionary stages of geological evolution.

Several numerical investigation methods have been developed to describe groundwater flow in karstified carbonate systems, including equivalent porous media (EPM), dual continuum, combined discrete-continuum, discrete fracture network (DFN) and discrete channel network approaches (Ghasemizadeh et al., 2012). Selection of an appropriate method primarily depends on the given hydrogeological problem to be solved and questions to be answered, as well as additional issues including the system scale, the degree of karstification and data availability (Scanlon et al. 2003).

As found by Kiraly (1975) and demonstrated by Sauter (1992), the average permeability in carbonate formations increases with increasing scale due to deep fractures and major faults and conduits, which can form preferred groundwater flow paths. At the basin scale, however, these local effects are less important (Wellman and Poeter, 2006), and the flow system can be considered as representing an integrated ensemble of matrix, fracture and channel processes. Local effects of karstic heterogeneities on formation permeability, such as karst conduits, tend to average out over larger areas, and may be neglected on this scale as suggested by Abusaada and Sauter (2013).

Since the current study focuses on regional groundwater flow patterns and heat transport processes rather than on more detailed, local predictions of flow directions or rates, an equivalent porous medium (EPM) approach (Teutsch and Sauter, 1991) was applied. We thus apply bulk parameters instead of incorporating small-scale matrix properties and individual fractures and conduits based on Lapcevic et al. (1999). The EPM approach has been used effectively in the past to simulate groundwater flow on regional scales and for slightly karstified carbonate aquifers (ex. Loáiciga et al., 2000; Rodríguez et al., 2013; Scanlon et al., 2003; Wellman and Poeter, 2006). The applicability of the EPM approach and the concept of gravity-driven regional groundwater flow for such carbonate systems was justified by Mádl-Szőnyi and Tóth (2015) based on the principle of hydraulic continuity, which was derived and shown effective for carbonate basins by Klimchouk (2009). Local heterogeneities in hydraulic conductivities were also neglected by Wellman and Poeter (2006) in order to evaluate the regional effect of the water table. Instead of focusing on local heterogeneities, in 


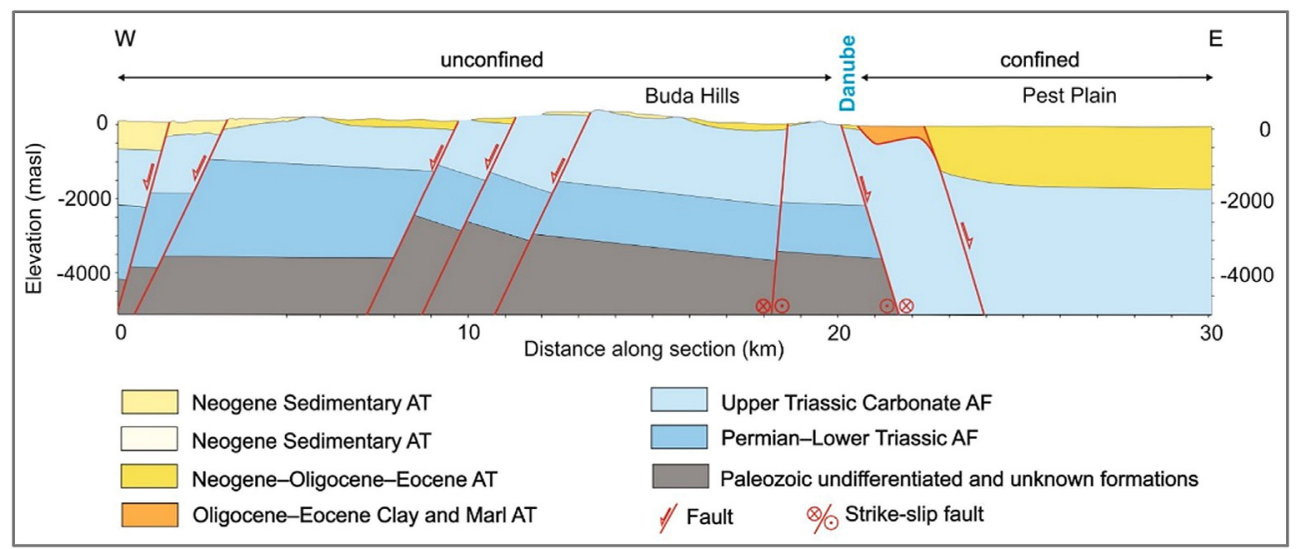

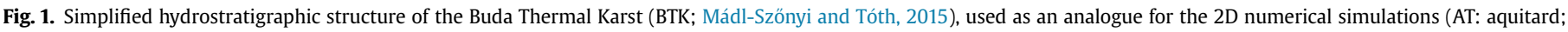
AF: aquifer).

this study we place more emphasis on the geometry of the basin, the slope of the water table, the thickness of the siliciclastic cover and their combined impact on flow patterns, following the preliminary approach of Mádl-Szőnyi and Tóth (2015).

Simplified, semi-synthetic snapshot models were simulated in a 2D vertical plane using the Heatflow-Smoker finite element model (Molson and Frind, 2015) which couples density-dependent groundwater flow and heat transport. The thermal transport model is based on solutions to the saturated density-dependent groundwater flow equation, and on a modified form of the advection-dispersion equation.

The continuity equation for flow can be expressed as:

$\frac{\partial}{\partial x_{i}}\left[K_{i, j}(T)\left(\frac{\partial \Psi}{\partial x_{j}}+\rho_{r}(T) \cdot \overline{n_{j}}\right)\right]=S_{s} \frac{\partial \Psi}{\partial t}$

where $x_{i}$ are the $3 D$ spatial coordinates $(m), K_{i, j}(T)$ is the temperature-dependent hydraulic conductivity tensor $\left(\mathrm{ms}^{-1}\right), \psi$ is the equivalent freshwater head $(\mathrm{m}), \rho_{\mathrm{r}}(\mathrm{T})$ is the temperaturedependent relative density of water $(-), S_{S}$ is the specific storage $\left(\mathrm{m}^{-1}\right)$, and $\mathrm{t}$ is time (s) (Bear, 1972; Frind, 1982). The temperaturedependent fluid density and viscosity functions used to define the hydraulic conductivity term were based on polynomials regressed from data in Weast (1980) over the temperature range $0-100{ }^{\circ} \mathrm{C}$ (Molson and Frind, 2015).

The governing thermal transport equation for a porous medium can then be expressed as:

$\frac{\partial}{\partial x_{i}}\left[\left(\kappa+\frac{D_{i j}}{R}\right) \frac{\partial T}{\partial x_{j}}\right]-\frac{\partial}{\partial x_{i}}\left(\frac{v_{i}}{R} T\right)=\frac{\partial T}{\partial t}$

where $\mathrm{T}$ is the temperature $\left({ }^{\circ} \mathrm{C}\right), \mathrm{D}_{\mathrm{ij}}$ is the hydrodynamic dispersion tensor $\left(\mathrm{m}^{2} \mathrm{~s}^{-1}\right)$ as given by Molson et al. (1992), $\mathrm{v}_{\mathrm{i}}$ is the average linear groundwater velocity $(\mathrm{m} / \mathrm{s}), \kappa$ is the thermal diffusivity $\left(\mathrm{m}^{2} \mathrm{~s}^{-1}\right)$ and $\mathrm{R}$ is the thermal retardation (-). The thermal diffusivity is defined by

$\kappa=\frac{\lambda}{C_{0}}$

where $\lambda$ is the thermal conductivity of the porous medium $\left(\mathrm{Jm}^{-1} \mathrm{~S}^{-1}{ }^{\circ} \mathrm{C}^{-1}\right)$ and $\mathrm{C}_{\mathrm{o}}$ is the heat capacity $\left(\mathrm{Jm}^{-3}{ }^{\circ} \mathrm{C}^{-1}\right)$ given by:
$C_{0}=\eta c_{w} \rho_{w}+(1-\eta) c_{s} \rho_{s}$

where $\eta$ is the porosity, $c_{w}$ and $c_{s}$ are the specific heat capacities $\left(\mathrm{Jkg}^{-1}{ }^{\circ} \mathrm{C}^{-1}\right.$ ) of the fluid (water) and solids, respectively, and $\rho_{w}$ and $\rho_{s}$ are the respective phase densities $\left(\mathrm{kgm}^{-3}\right)$. The thermal retardation factor $\mathrm{R}$ in Equation (2) can be defined as:

$R=\frac{C_{0}}{\eta \cdot c_{w} \rho_{w}}$

The model uses deformable rectangular prism elements and the final matrix equations for both the flow and thermal transport problems are solved using an efficient preconditioned conjugate gradient (PCG) solver for symmetric matrices (Schmid and Braess, 1988). Further details are provided in Molson and Frind (2015).

\section{Numerical simulations}

\subsection{Conceptual model design issues}

Three main issues were first addressed to help develop a realistic conceptual model: i) configuration of the water table, ii) model dimensionality (2D or 3D), and iii) relevance of buoyancy as a driving force for groundwater flow.

\subsubsection{Configuration of the water table}

The numerical investigation based on the BTK system focuses on regional-scale fluid and heat transport within the saturated zone of a carbonate system, for which the water table forms the upper surface. Under conditions of differential basin uplift, the water table gradients act as the principal driving forces for groundwater flow (Goldscheider et al., 2010; Tóth, 2009) and thus the relation of the water table to surface topography becomes a critical factor in shaping the flow system.

In this context, Haitjema and Mitchell-Bruker (2005) offered a simple dimensionless decision criterion to distinguish between recharge- and topography-controlled water table configurations for numerical simulations. Based on the average annual recharge rate $\left(\mathrm{q}\left[\mathrm{md}^{-1}\right]\right)$, the average distance between hydraulic boundaries ( $\mathrm{L}$ $[\mathrm{m}])$, an aquifer shape factor (m [-]), the horizontal hydraulic conductivity $\left(\mathrm{K}\left[\mathrm{md}^{-1}\right]\right)$, the aquifer thickness ( $\mathrm{H}[\mathrm{m}]$ ), and the maximum distance between the average surface water levels and the terrain elevation $(\mathrm{d}[\mathrm{m}])$, the following ratio was defined: 


$$
\alpha=\frac{q L^{2}}{m K H d}
$$

If $\alpha>1$, the water table is topography controlled, and should follow a subdued replica of the terrain surface. In this case, groundwater flow is dominated by local circulation in a hierarchically nested flow domain. In comparison, for $\alpha<1$, the water table is recharge-controlled and shows moderate to small degrees of groundwater mounding in response to average recharge. Areas in such settings have subordinate local components of groundwater flow, while the major flow component is regional (Haitjema and Mitchell-Bruker, 2005). Recharge-controlled water tables are common in arid, rugged, or high-permeability terrain where actual recharge rates are less than the potential infiltration capacity, and a larger proportion of flow is regional.

Due to the higher hydraulic conductivity of carbonate ranges compared to siliciclastic environments at the basin scale (MádlSzőnyi and Tóth, 2015), we can expect dominantly rechargecontrolled systems in semi- or unconfined carbonate regions. Based on site-specific values of the analogue pilot area, the ratio was indeed $\alpha<1$, therefore the configuration of the water table was defined as recharge-controlled.

\subsubsection{Dimensionality}

Based on the study of Gleeson and Manning (2008), the ratio of recharge to hydraulic conductivity in the uppermost layer of a flow system can be used to select the appropriate dimensionality for simulating groundwater flow. They showed that for low-relief settings, where the $\mathrm{R} / \mathrm{K}$ ratio is $<0.15,2 \mathrm{D}$ cross-sectional models may be justifiable since transverse flow (perpendicular to the primary regional topographic gradient) would be generally $<10 \%$ of the total flow. However if $\mathrm{R} / \mathrm{K}>0.15$, a $3 \mathrm{D}$ approach would be needed. In the case of the analogue pilot area, the $2 \mathrm{D}$ criterion was satisfied, therefore a 2D numerical approach is justified for simulating groundwater flow.

\subsubsection{Relevance of buoyancy as a driving force}

Buoyant convection (or "free" convection) can occur in geological systems in which the permeability and geothermal gradient are sufficiently high. The relative strength of thermal conduction vs. convection can be determined by the Rayleigh number $\left(R_{a}\right)$, which is a dimensionless ratio that determines the onset of thermal free convection, defined as follows:

$R_{a}=\frac{\alpha_{T} \cdot g \cdot \rho^{2} c_{w} k\left(y^{2}\right) \cdot \gamma}{\mu \cdot \lambda}$

where $\alpha_{T}$ is the coefficient of thermal expansion for water $\left(2.14 \times 10^{-4}{ }^{\circ} \mathrm{C}^{-1}\right), \mathrm{g}$ is the acceleration due to gravity $\left(9.81 \mathrm{~ms}^{-1}\right), \rho$ is the water density $\left(1000 \mathrm{kgm}^{-3}\right), \mathrm{c}_{\mathrm{w}}$ is the water specific heat capacity $\left(\mathrm{Jkg}^{-1}{ }^{\circ} \mathrm{C}^{-1}\right), \mathrm{k}\left(\mathrm{m}^{2}\right)$ is the permeability, $\mathrm{y}(\mathrm{m})$ is the height of the medium, $\gamma\left({ }^{\circ} \mathrm{Cm}^{-1}\right)$ is the vertical thermal gradient, and $\mu$ $\left(\mathrm{kgm}^{-1} \mathrm{~s}^{-1}\right)$ is the water dynamic viscosity. Assuming $\mu=0.0004 \mathrm{kgm}^{-1} \mathrm{~s}^{-1}$, with $\lambda=2.5 \mathrm{~W} \mathrm{~m}^{-1}{ }^{\circ} \mathrm{C}^{-1}$, a $4000 \mathrm{~m}$ deep carbonate system with $\gamma=0.05{ }^{\circ} \mathrm{C} \mathrm{m}^{-1}$ (characteristic for the analogue pilot area, Lenkey et al., 2002), then a minimum permeability of $\mathrm{k}=5.7 \times 10^{-15} \mathrm{~m}^{2}$ (equivalent to $\mathrm{K}=5.7 \times 10^{-8} \mathrm{~ms}^{-1}$ ) is required for the onset of buoyancy, based on the critical value $\mathrm{R}_{\mathrm{a}}^{*}=4 \pi^{2} \approx 40$ (Turcotte and Schubert, 1982).

Comparing this conductivity with the range of hydraulic conductivities of karst limestone, limestone and dolomite $\left(2 \times 10^{-2}-10^{-6} \mathrm{~ms}^{-1}\right.$, with a minimum value of $\left.10^{-9} \mathrm{~ms}^{-1}\right)$ (Domenico and Schwartz, 1990), we can surmise that conditions would indeed be favorable for development of thermal convection cells in the studied $4000 \mathrm{~m}$ thick carbonate unit.

While temperature-dependent fluid density and viscosity was included in the model, for simplicity, the effect of density-driven flow due to high total dissolved solids (TDS) concentrations was neglected. This issue will be addressed in future studies.

\subsection{Simulation scenarios}

\subsubsection{Conceptual models of geological evolution}

Three cases were defined based on the main geological evolutionary stages of the pilot area. Scenario modelling was subsequently carried out in order to examine the effects of tectonic uplift and erosion of confining siliciclastic strata above the carbonates.

The main goal was to gain insight into the effect of decreasing thickness of the low-permeability confining layer on the flow field and heat distribution. A simplified geological and hydrostratigraphic conceptual model was therefore applied. Moreover, with such relatively simple settings, the groundwater flow distribution and heat transport processes are easily comparable for the different evolutionary stages. The basic geometry of the flow domain followed the existing conceptual model of Mádl-Szönyi and Tóth (2015) (Fig. 1). Consequently, simulated changes in the flow field that could lead to changes in heat distribution, as well as identifying the relative importance of gravity and buoyancy could be more easily determined.

As an initial condition for the geological evolution, a fully confined carbonate system was simulated, characteristic of the Late Miocene (11.6-5.3 Ma) in the analogue pilot area (Stage 1, Fig. 2a). An $800 \mathrm{~m}$ thick low-permeability sedimentary cover was assumed to overlie the $3200 \mathrm{~m}$ thick permeable carbonate unit. A flat water table, assigned as a fixed-head upper boundary, represented the initial condition before the area became subaerially exposed due to sea regression. The simulation parameters are provided in Fig. 2 a and in Table 1.

In the next evolutionary stage (Stage 2, Fig. 2b), the thickness of the cover formation along the left (western) part of the system was reduced. This situation represents the consequences of erosion and re-deposition due to vertical uplift of the left subregion, and later, initiation of uplift of the right side. Uplift led to the differentiated increase of topographic elevations along the boundaries of the delineated subsurface section. Additionally, an erosion base evolved between the uplifting blocks (coinciding with what would eventually become the Danube River in the case of the analogue pilot area). Increased thickness of the cover formation along the right sub-basin, in parallel with the uplift of the left part, represents accumulation of sediment from the neighboring elevated areas. This situation represents the conditions for the analogue study area during the Late Pliocene (3.6-2.58 Ma) (Fig. 2b).

Additional uplift along the left sub-basin led to the complete erosion of the cover unit in this area, which produced unconfined conditions represented by the last evolutionary stage (Stage 3, Fig. 2c). The right sub-basin remains confined, since uplift of this side started later. The maximum height of the water table is assumed to be $31 \mathrm{~m}$ at the left boundary and $26 \mathrm{~m}$ at the right boundary relative to the erosion base ( $\Psi=0 \mathrm{~m}$ fixed head) based on Mádl-Szőnyi and Tóth (2015).

\subsubsection{Input parameters, initial and boundary conditions of the models}

Hydraulic conductivity and porosity values of the semisynthetic models were constant for all tested stages and were estimated based on global physical properties of the carbonate and siliciclastic reservoirs (Ehrenberg and Nadeau, 2005). Additionally, information from site-specific hydrostratigraphic and numerical studies of the pilot area (Martinecz et al., 2014; Mádl-Szőnyi and 


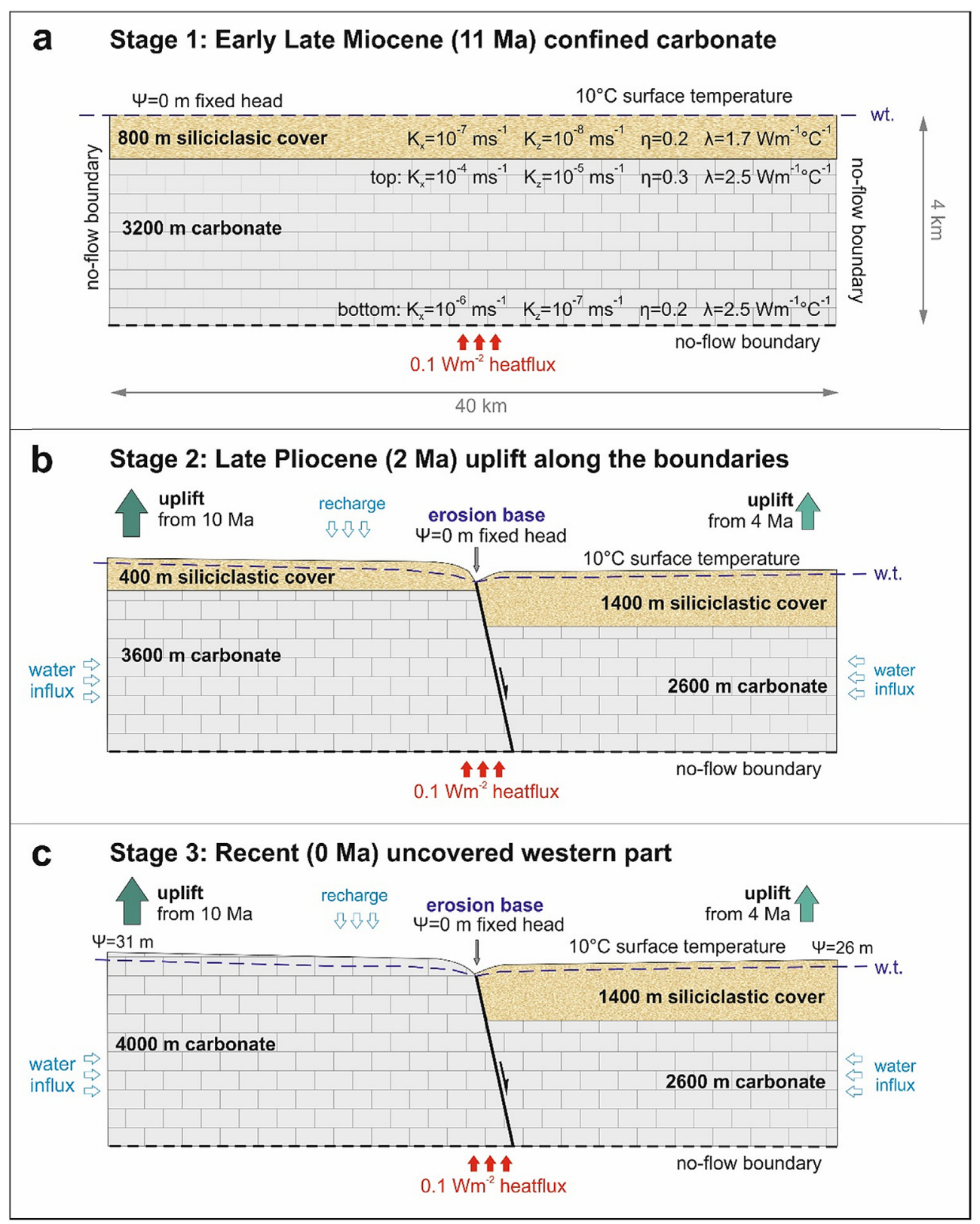

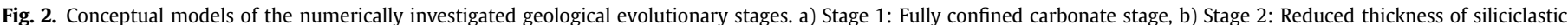

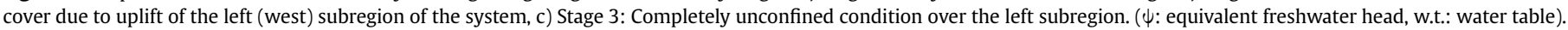

Tóth, 2015) were also considered. Following the EPM approach, fracture networks and karstic channels were not integrated into the model as discrete elements. However, bearing in mind the scaledependency of porosity and hydraulic conductivity values revealed by Kiraly (1975), these observed hydraulic properties of the carbonate unit were slightly increased in the model to account for regional fracture networks and interconnected karstic channels which tend to increase the hydraulic conductivity and porosity on the regional (aquifer) scale compared to the local (borehole) scale.

Extrapolation of the measured and interpreted dataset with depth remained an issue. Based on the study of Ehrenberg and Nadeau (2005), carbonate reservoirs from a global perspective show apparent linear decreases in porosity as well as in permeability with increasing depth. However, Jiang et al. (2009) demonstrated that the nonlinear depth-dependent decrease in $\mathrm{K}$ enhances penetration depths of local flow systems by decreasing the intensity of the deeper flow systems, and therefore, the depth decay of $\mathrm{K}$ should not be neglected when analyzing hydrologic problems related to regional groundwater flow. Based on this consideration, an exponential decrease of hydraulic conductivity was defined for the carbonate suite, with the horizontal conductivity $\left(\mathrm{K}_{\mathrm{x}}\right)$ ranging from $10^{-4} \mathrm{~ms}^{-1}$ at the top to $10^{-6} \mathrm{~ms}^{-1}$ at the bottom of the section. Since the main focus of the simulation was on the flow and heat transport processes acting in the carbonate unit, and since the hydraulic conductivity contrast between the carbonate and the overlying cover unit is high (3 orders of magnitude), the decrease of $\mathrm{K}$ with depth in the siliciclastic cover unit was neglected, and a uniform horizontal hydraulic conductivity of $10^{-8} \mathrm{~ms}^{-1}$ was defined for the cover. Anisotropy of the units was characterized by a one order of magnitude lower vertical conductivity $\left(\mathrm{K}_{\mathrm{z}}\right)$ (thus assuming an anisotropy ratio $\mathrm{K}_{\mathrm{z}} / \mathrm{K}_{\mathrm{x}}=0.1$ ).

We assume a uniform bulk thermal conductivity of $1.7 \mathrm{~W} / \mathrm{m} /{ }^{\circ} \mathrm{C}$ 
Table 1

Summary of input parameters, initial and boundary conditions for the simulation scenarios.

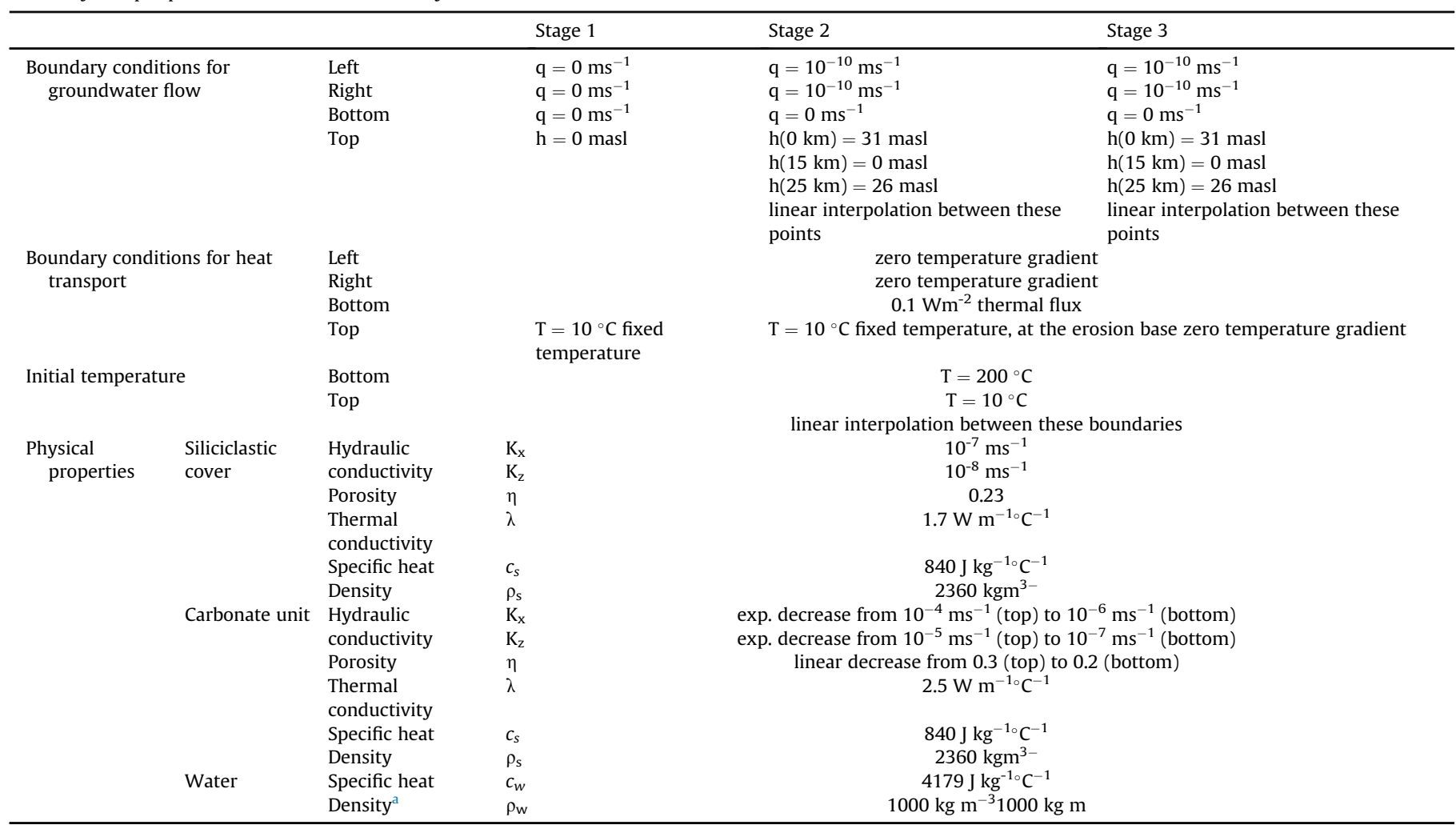

a Water density is temperature-dependent.

for the siliciclastic cover and $2.5 \mathrm{~W} / \mathrm{m} /{ }^{\circ} \mathrm{C}$ for the carbonate unit, derived from Rman and Tóth (2011) and Mádl-Szőnyi and Tóth (2015).

Boundary conditions for groundwater flow vary depending on the different geological stages. In Stage 1 (Fig. 2a) which can be considered as an initial stage, the lower boundary was defined based on the hydrostratigraphic section of the analogue area, where low permeability Paleozoic formations underlie the carbonate unit, and therefore the bottom of the system can be treated as a no-flow boundary due to the high (4 orders of magnitude) hydraulic conductivity contrast (Martinecz et al., 2014). For this theoretical scenario, geological and hydrogeological information was not available regarding the probable margins of the system. Therefore the lateral boundaries of the section were simply defined as being closed by assuming no-flow boundaries as a base case in order to delineate a subsurface area with a homogeneous cover of siliciclastic sediments. At the top, a uniform and flat water table was assumed with a hydraulic head $(\psi)$ of 0 masl, which represents the conditions before the area became subaerially exposed.

In Stage 2 (Fig. 2b) and Stage 3 (Fig. 2c), the lower boundary was again assumed to be impermeable based on the previously mentioned considerations, while along the vertical lateral boundaries a water influx (Table 1) was assigned to reflect assumed higher water table elevations beyond the simulated domain which would cause fluid inflow. The upper flow boundary was a fixedhead boundary with a linear decrease of the water table from the left boundary to the erosion base, as well as a linear increase of the water table from the erosion base to the right boundary. This water table shape represents meteoric water infiltration into the system due to uplift.

Across the bottom boundary, a heat flux of $100 \mathrm{mWm}^{-2}$ was defined, while the initial basal temperature of $200{ }^{\circ} \mathrm{C}$ was derived from this heat flux and the $40{ }^{\circ} \mathrm{Ckm}^{-1}$ geothermal gradient, which is characteristic for the analogue pilot area (Lenkey et al., 2002). A constant ground surface temperature of $10^{\circ} \mathrm{C}$ was assumed in all cases based on an estimated mean annual temperature representative of the pilot area over the geological time frame. For simplicity, effects of variable surface temperature due to climatic changes were neglected. Lateral boundaries were set as zero temperature-gradient boundaries, thus assuming no conductive heat transfer (Table 1) (advective heat flow is assumed dominant across these open-flow boundaries).

The $25 \mathrm{~km}$ wide and $4 \mathrm{~km}$ deep model domain was subdivided into a regular network of $100 \mathrm{~m} \times 100 \mathrm{~m}$ rectangular prism finite elements (using $250 \times 40$ elements, and 1 element wide in the transverse dimension). The simulations were run over $110 \mathrm{kyr}$, with a time step of $1 \mathrm{yr}$. Hydraulic head distributions and the corresponding temperature fields of all scenarios were plotted at $110 \mathrm{kyr}$. The simulated time interval was verified sufficient to reach a quasi steady-state solution (with temporally repeating similar patterns over geologic time scales) for each stage.

\section{Results}

\subsection{Stage 1}

In this fully confined system state, the water table is flat and there are no imposed hydraulic gradients which could generate topography-driven flow. Nevertheless, complex buoyancy-driven hydrothermal convective flow systems evolve within the permeable carbonate unit (Fig. 3a), which are maintained due to the heat insulating role of the low-conductivity siliciclastic confining formation (seen in the temperature field of Fig. 3b). Convective flow cells are easily formed as the Rayleigh number $\left(R_{a}=360\right)$ exceeds 


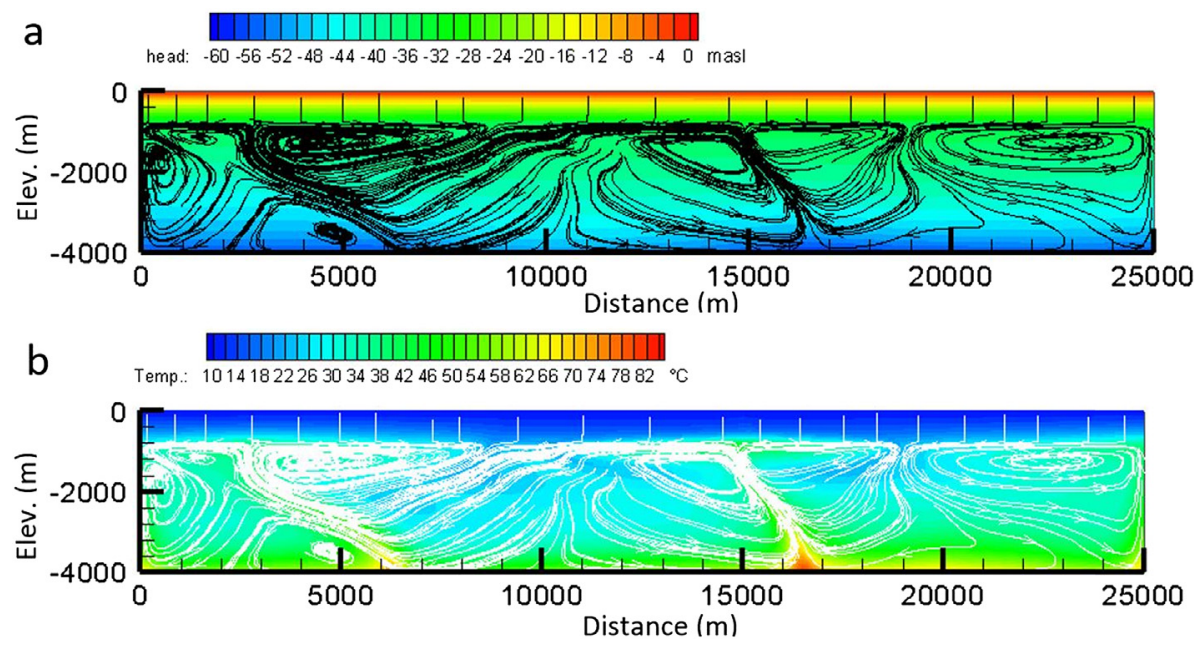

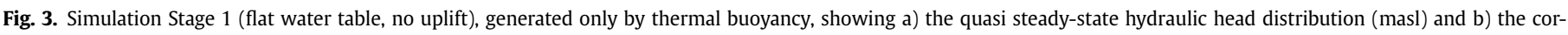
responding temperature field, after $110 \mathrm{kyr}$. The (same) quasi-steady flow system after $110 \mathrm{kyr}$ is superimposed in both cases.

the critical value by almost a factor of 10 . This setting leads to the development of a vigorous, dynamic system with transient convection cells where some cells gradually dissipate with time while new ones are born, eventually reaching a quasi steady-state pattern within the $110 \mathrm{kyr}$ time frame. In this initial case of geologic evolution, the flow and temperature fields are clearly dominated by natural thermal convection, with maximum temperatures at the base reaching $75-85{ }^{\circ} \mathrm{C}$, which is consistent with the independently-estimated fluid inclusion temperatures for this stage (Poros et al., 2012). (Note that following Equation (1), contour plots of the equivalent freshwater head $(\psi)$ cannot be used alone to infer flow directions since the driving force also includes the relative density term. We will later show vertical profiles of the ratio of these terms (Fig. 8) to help interpret the relative importance of gravity vs. buoyancy).

\subsection{Stage 2}

Due to the differential uplift represented in Stage 2, the thickness of the siliciclastic cover over the left side block gradually decreased by erosion. On the relatively lower, right (eastern) side of the system, sediment accumulated concurrently with the uplift of the western block, which increased the thickness of the confining formations. Due to topographic changes, differences also evolved in the water table, which facilitated the development of gravitydriven groundwater flow.

First, if we take into account only the effect of gravity as the driving force, the flow pattern is relatively simple, groundwater flows from the elevated marginal areas to the erosion base in accordance with the hydraulic head differences and hydraulic conductivities (Fig. 4a). However, since the Rayleigh number $\left(R_{a}\right)$ is between 240 and 455 within the carbonates (depending on the thickness of the confining formation), thermal convection is still important, and thus including coupled gravity and buoyant flow significantly changes the generated flow pattern (Fig. 4b).

Although the coupled density-dependent flow system in Stage 2 reflects the dominance of buoyancy as the driving force, the increased water table gradient due to uplift has initiated a strong component of gravity-driven groundwater flow which has slightly shifted water flow downwards toward the erosion base in the confining strata. The limited thickness of the siliciclastic cover along the western block compared to the eastern side has allowed fresh and cool water infiltration into the system, which leads to increased cooling in this area (average temperatures decreased from approx. $35^{\circ} \mathrm{C}$ (in Stage 1, Fig. 3 b) to approx. $25^{\circ} \mathrm{C}$ within the carbonate in the left part) (Fig. 4c). Convection cells could therefore not as easily build up in this western part as in the previous stage and have shifted slightly towards the eastern part of the system.

\subsection{Stage 3}

In Stage 3, representing current conditions, further uplifting of the western part leads to increased infiltration from the western side, resulting in an asymmetric flow pattern (Fig. 5a). The uplift causes the main character of the flow pattern to evolve from buoyancy-driven flow to dominantly gravity-driven groundwater flow (Fig. 5b). This is particularly evident along the uncovered western part of the system, where flow intensity has increased due to the high permeability of the carbonates and from increased meteoric infiltration. The highest flow rates are in the upper part of the permeable carbonates within the unconfined sub-system, where cooling of the system has significantly progressed (average temperatures decreased from $25{ }^{\circ} \mathrm{C}$ to approx. $15{ }^{\circ} \mathrm{C}$ within the upper section of carbonate in the unconfined part) (Fig. 5c). However, conditions over the confined eastern part of the system (where $R_{a}=240$ within the carbonates) are still favorable for the development of convection cells.

The asymmetric flow pattern is also attributable to the more intense meteoric infiltration over the unconfined part of the system compared to the confined part. This condition and the insulating role of the cover formation leads to significant heat accumulation under the confined sub-basin.

\section{Interpretation and discussion}

Variations of temperature with depth along three vertical profiles located at distances of $2 \mathrm{~km}, 15 \mathrm{~km}$ and $23 \mathrm{~km}$ from the left boundary of the system during the three evolutionary stages show useful insight into the coupled gravity-buoyancy-controlled system behavior (Fig. 6). The three profiles represent recharge, discharge and recharge areas, respectively, and were plotted at $110 \mathrm{kyr}$, as in the 2D simulated flow patterns and temperature fields (Figs. 3-5). Because the coupled system is thermally unstable, a final steadystate condition is never reached but it eventually settles down to a quasi-equilibrium state in which convection cells develop and disappear but with some regularity. These profiles therefore 


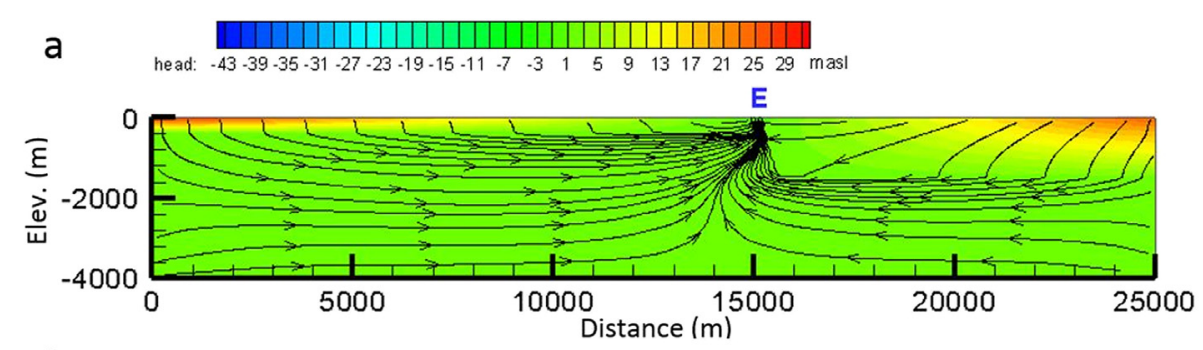

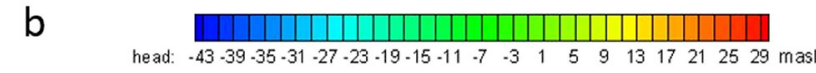

E

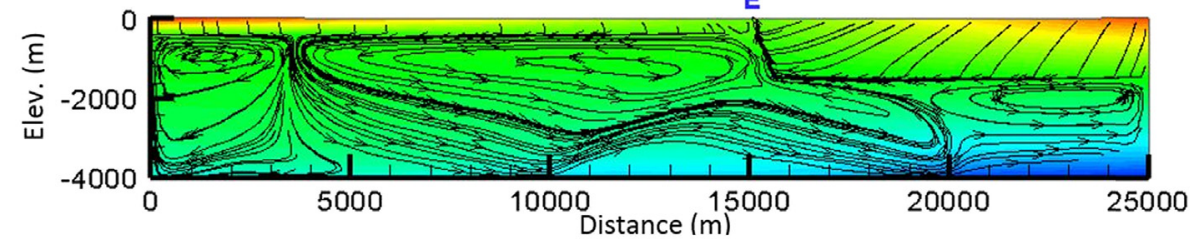

C $\quad \underset{\text { Temp.: }}{1014182226303438424650545862667074788286{ }^{\circ} \mathrm{C}}$

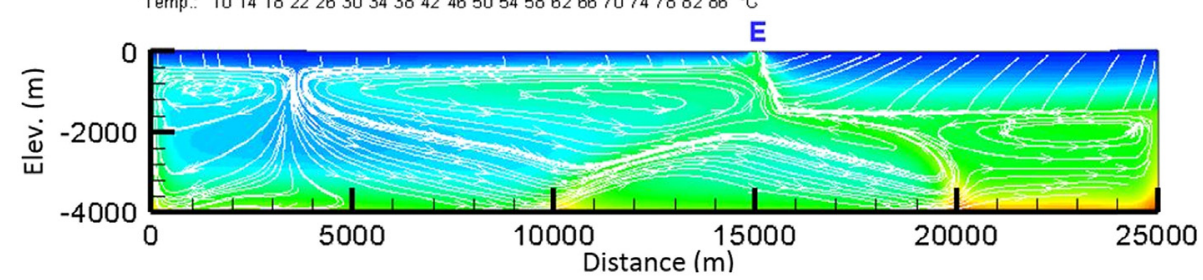

Fig. 4. Simulation Stage 2 (Erosion base (E), limited uplift of western block) showing a) the steady-state hydraulic head distribution and flow patterns generated only by the water table topography (no density effect), and b) the quasi steady-state hydraulic head, and c) the temperature field, from a single otherwise identical simulation after 110 kyr, but considering both gravity and buoyancy. The (same) quasi-steady flow system after $110 \mathrm{kyr}$ for the coupled case (b \& c) is superimposed on both plots.

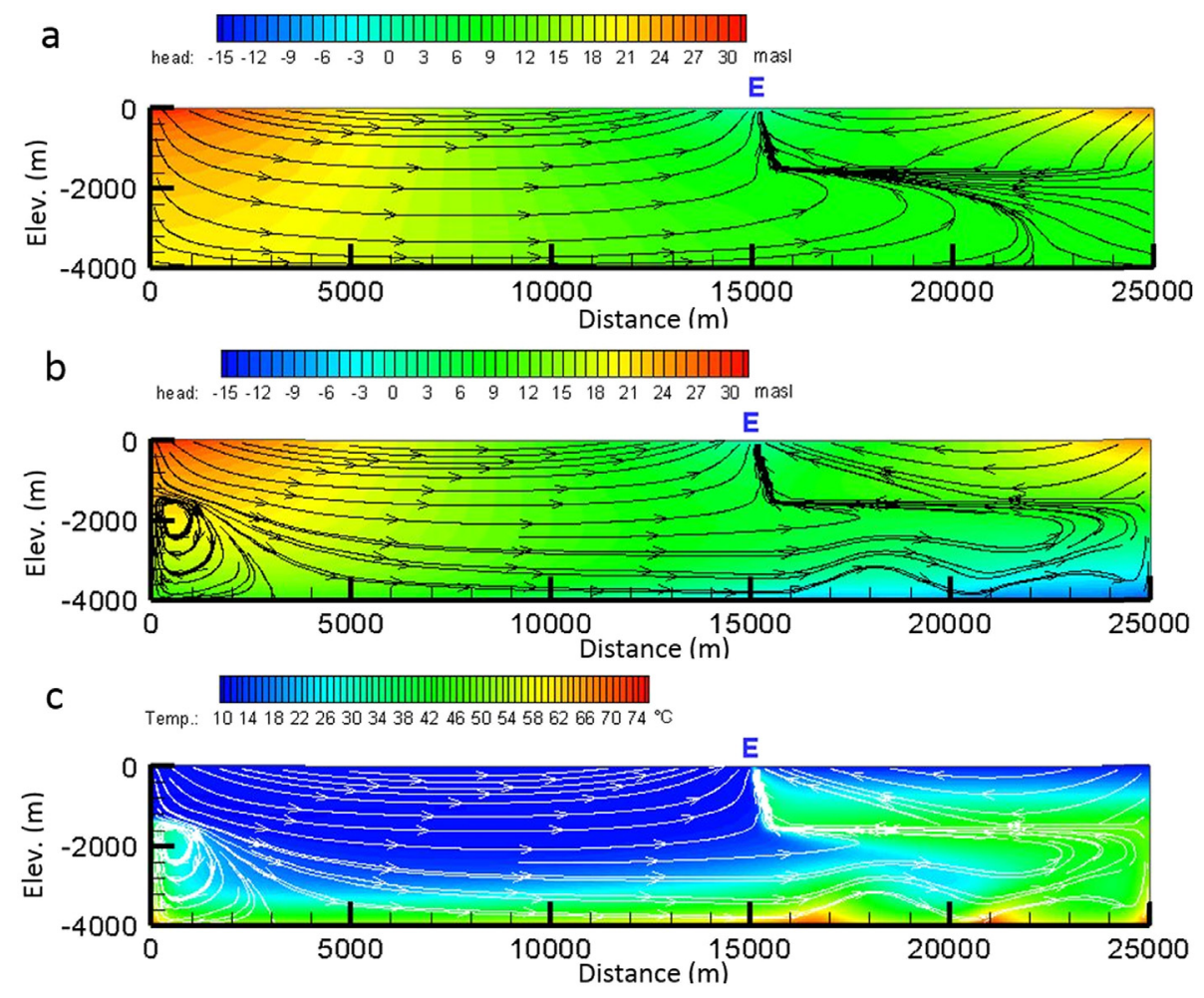

Fig. 5. Simulation Stage 3 (Erosion base (E), additional uplift of western block) showing a) the hydraulic head distribution and flow patterns generated by only the water table topography, and in b) and c) an otherwise identical simulation after $110 \mathrm{kyr}$, but considering both gravity and buoyancy, showing b) the quasi steady-state hydraulic heads and c) the temperature field. The (same) quasi-steady flow system after $110 \mathrm{kyr}$ for the coupled case (b \& c) is superimposed on both plots.

Please cite this article in press as: Havril, T., et al., Evolution of fluid flow and heat distribution over geological time scales at the margin of unconfined and confined carbonate sequences - A numerical investigation based on the Buda Thermal Karst analogue, Marine and Petroleum Geology (2016), http://dx.doi.org/10.1016/j.marpetgeo.2016.10.001 


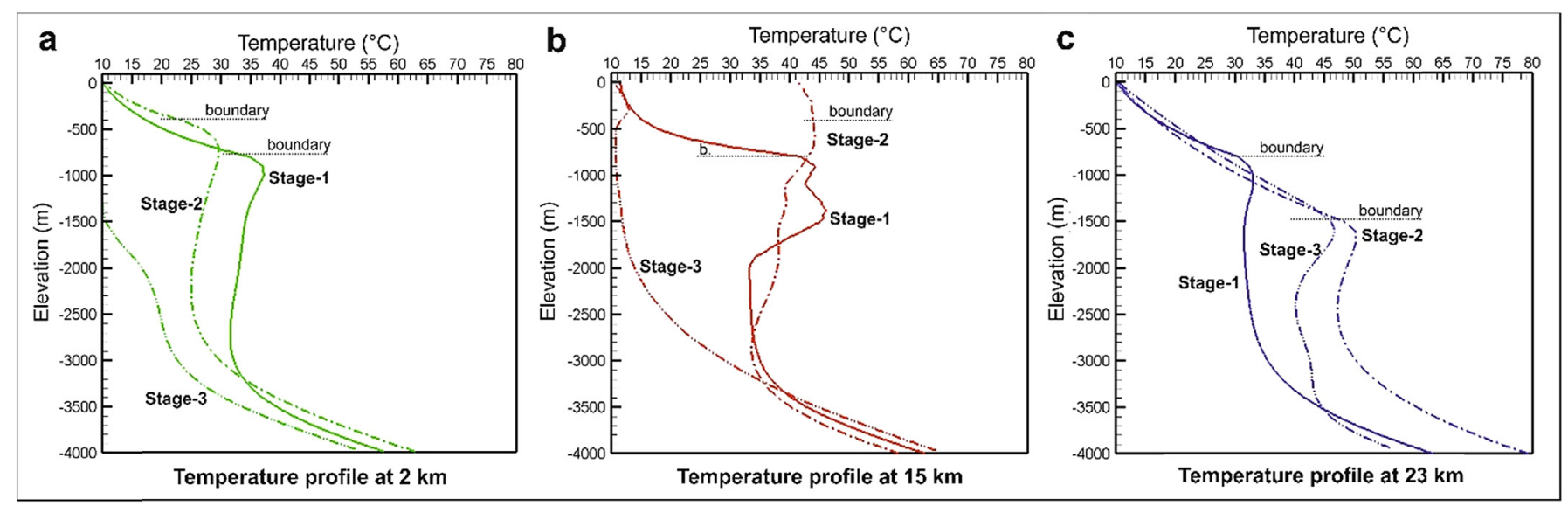

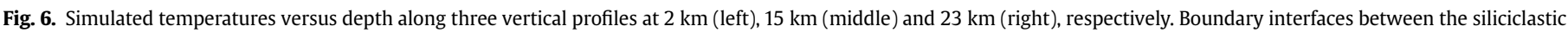
cover and the carbonate formation of the different stages are indicated on each profile.

represent snapshots of a transient progression, and are appropriate only to determine relative conditions and processes acting during system evolution. Nevertheless, several interesting trends can be seen.

At the $2 \mathrm{~km}$ profile (Fig. 6a), within the upper $3 \mathrm{~km}$, the temperatures generally decrease from Stage 1 to Stage 3 due to increasing recharge of cooler meteoric water as the left system is uplifted and becomes unconfined. In the temperature profiles at $15 \mathrm{~km}$ (corresponding to the minimum water table elevation in Stage 2 and 3), relatively lower temperatures in the upper $1000 \mathrm{~m}$ can also be observed in Stage 3 (Fig. 6b), since this is where the infiltrated cooler water from the western (left) part of the system (and some from the right) is discharging. In contrast, below the constantly confined right part of the system at $23 \mathrm{~km}$, between elevations of about -1000 and $-3500 \mathrm{~m}$ (Fig. 6c), temperatures in Stage 2 and 3 are higher than in Stage 1 since the confining layer thickness has increased here and thus its insulating effect increases over time. Also, the increasing gravitationally-controlled flow system in Stage 3 diverts more flow to the right and deeper below the right confining layer where it becomes heated from the geothermal gradient before rising at the far right and discharging at the $15 \mathrm{~km}$ erosion base (see also Fig. $5 \mathrm{c}$ ). As also observed in the profiles at $2 \mathrm{~km}$ and $15 \mathrm{~km}$, the temperatures below $-1500 \mathrm{~m}$ at the $23 \mathrm{~km}$ profile decrease significantly from Stage 2 to Stage 3 due to the cooling effect of the meteoric water which infiltrates through the unconfined part of the system.

In the shallow subsurface through the confining layer at $2 \mathrm{~km}$ (Fig. 6a), the temperature increases roughly linearly with depth $(0$ to $-1000 \mathrm{~m}$ in Stage 1 and $0 \mathrm{~m}$ to $-500 \mathrm{~m}$ in Stage 2). At $23 \mathrm{~km}$ (Fig. 6c), a very similar linear trend is also evident ( 0 to $-1000 \mathrm{~m}$, where the confining layer thickness is uniform), which extends even deeper through the thicker confining layer in Stage 2 and 3 (0 to $-1500 \mathrm{~m}$ ). A linear thermal gradient results from the dominance of conductive heat transfer, since the Rayleigh number in this lowpermeability layer $\left(R_{a}=3\right)$ remains below the critical value $\left(\mathrm{R}_{\mathrm{a}}^{*}=40\right)$ and thus convection cells cannot form.

In comparison, the corresponding temperature profiles within the carbonate unit are non-linear, reflecting the additional effect of convective heat transfer, since the Rayleigh number in this unit $\left(R_{a}>455\right)$ significantly exceeds the critical value. Towards the base of all profiles (below about -3000 or $-3500 \mathrm{~m}$ ), the temperature increase with depth is again roughly linear, with about the same temperature gradient in all profiles, being controlled by the imposed geothermal flux and thermal conductivity.

Cyclic temperature variations at the model base (Fig. 7) are caused by the convection cells which are stage-specific, with periods dependent on the horizontal position along the section (i.e. whether below the confined or unconfined part). Below the left part of the system, where the thickness of the cover gradually decreases over time, the $30 \mathrm{kyr}$ period in Stage 1 (Fig. 7 a, point M-1) decreases to $15 \mathrm{kyr}$ in Stage 3 (Fig. 7 c, point M-1). In parallel, the period of the temperature variation cycles at the base of the constantly confined right part of the system also declines although by a smaller amount - from $20 \mathrm{kyr}$ (Stage 1, point M-3, Fig. 7a) to $15 \mathrm{kyr}$ (Stage 3, point M-3, Fig. 7c), thus suggesting that the period of cyclic temperature variations decreases during system evolution. This decreasing period (or increasing frequency) could be attributable to the increasing flow velocities (ex. $\mathrm{v}_{\mathrm{z}(\max )}$ increases from $5.5 \times 10^{-7} \mathrm{~ms}^{-1}$ in Stage 1 to $10^{-6} \mathrm{~ms}^{-1}$ in Stage 3) caused by more efficient meteoric water infiltration through the reduced thickness of the left cover, which leads to the development of a more dynamic flow system.

To gain insight into the relative importance of gravity and buoyancy as driving forces during the different evolutionary stages, the ratio of the vertical hydraulic gradient (of the equivalent freshwater head) to relative density, (i.e. $\nabla_{\mathrm{z}}(\psi) / \rho_{\mathrm{r}}$; see also Equation (1)) was plotted vs. depth (Fig. 8). Since the relative density in these cases is always negative, if this ratio is large and negative, then flow is downward (ex. in the recharge zones at $2 \mathrm{~km}$ and at $23 \mathrm{~km}$; Fig. 8a and c, respectively) while large positive ratios imply upward flow (ex. Stage 3 at $15 \mathrm{~km}$ representing discharge to the erosion base; Fig. 8b). In both cases of high positive or high negative ratios, flow is dominated by gravitational forces (since $\left|\nabla_{\mathrm{z}}(\psi)\right| \gg\left|\rho_{\mathrm{r}}\right|$ ). Ratios near zero imply that vertical gravity forces are low compared to thermal buoyancy (since $\left|\nabla_{\mathrm{z}}(\psi)\right| \ll\left|\rho_{\mathrm{r}}\right|$, although horizontal hydraulic gradients could still be dominant).

In Stage 1 at all profile locations, above about 1000 m elevation, the ratio of vertical hydraulic gradient to the relative density $\left(\nabla_{\mathrm{z}}(\psi)\right.$ ) $\rho_{\mathrm{r}}$ ) is negative (Fig. 8a, 8b and 8c). While this suggests downward gravity-dominant flow, the relatively low hydraulic conductivity of the continuous confining layer in Stage 1 limits any significant flow across this layer (see Fig. 3). Below about $1000 \mathrm{~m}$ in almost each stage and location, the ratio of vertical hydraulic gradient to the relative density is near zero, representing relatively strong buoyancy which induces the hydrothermal convection cells seen in Figs. 3-5. However, in Stage 3 at $2 \mathrm{~km}$, gravity-dominated downward flow (i.e. where $\nabla_{\mathrm{z}}(\psi) / \rho_{\mathrm{r}}<0$ ) extends significantly deeper, to a depth of about $2000 \mathrm{~m}$ due to the high water table elevation within the unconfined left part of the system (Fig. 8a). In contrast, at $15 \mathrm{~km}$, during Stage 2, the ratio remains close to zero at all depths which 


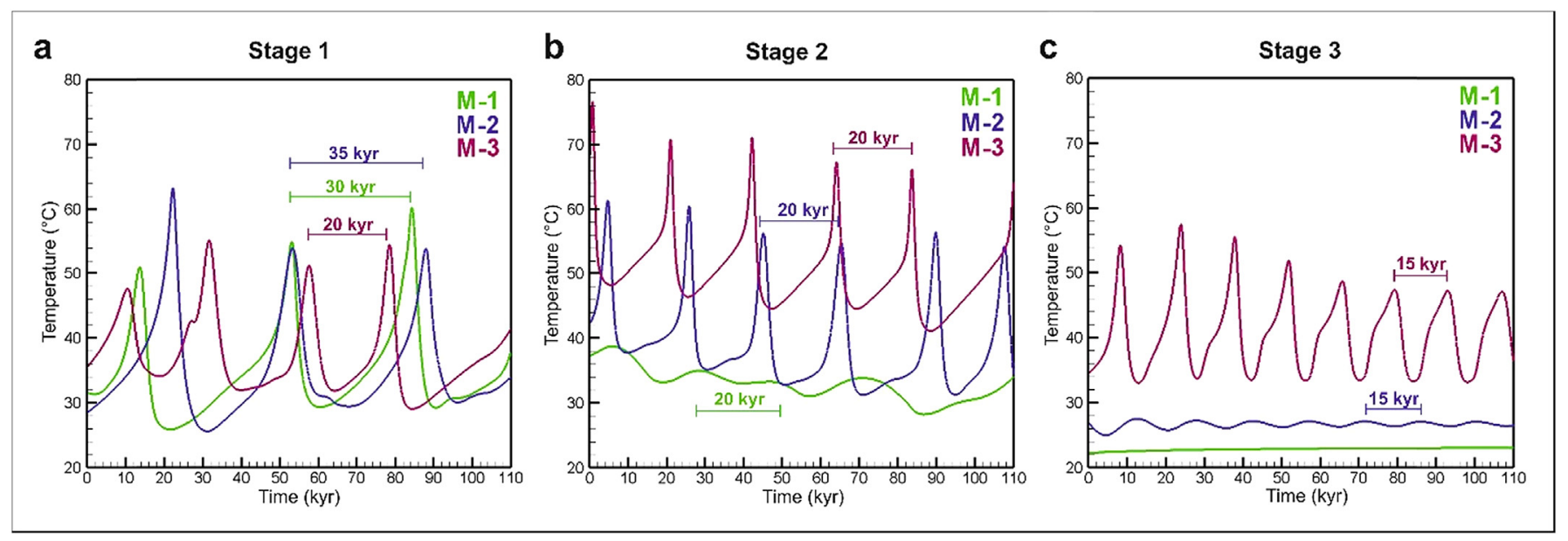

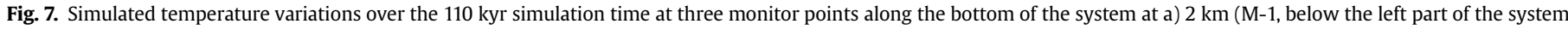
which became unconfined), b) $12.5 \mathrm{~km}$ (M-2, in the middle of the section) and c) $23 \mathrm{~km}$ (M-3, below the constantly confined part of the system).
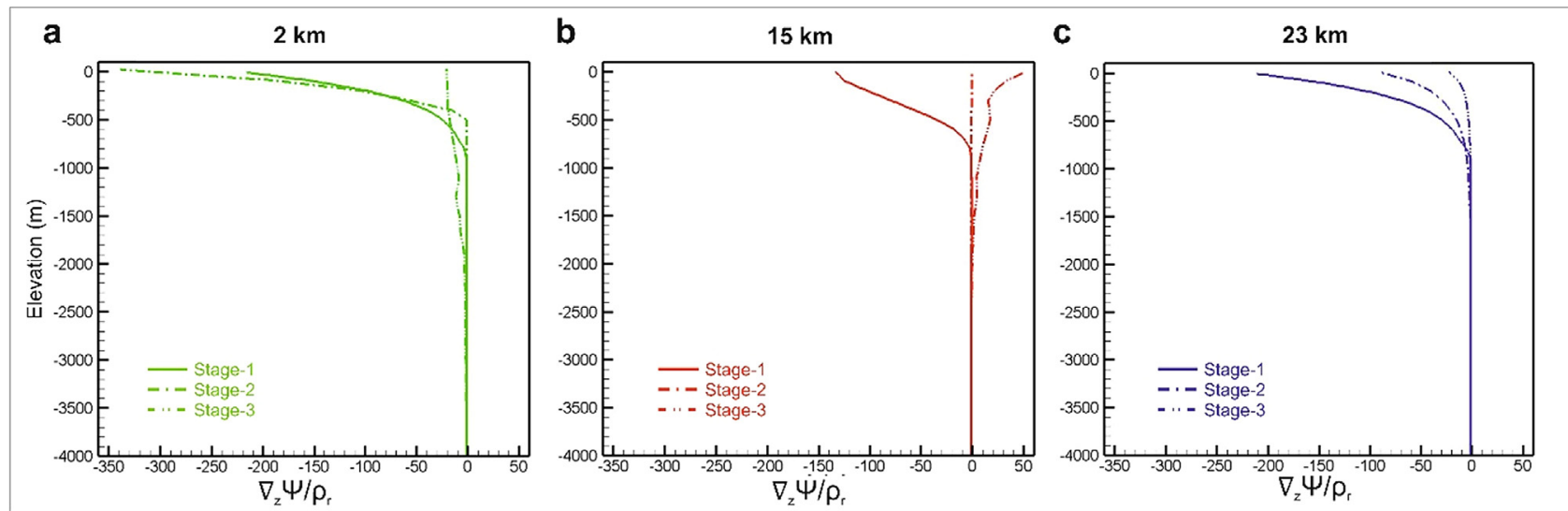

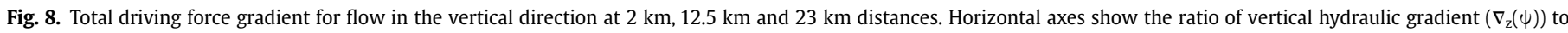
relative density $\left(\rho_{\mathrm{r}}\right)$.

suggests strong buoyancy flow throughout the profile, even at the erosion base where water is discharging, as confirmed in the convection cell-dominated flow system seen in Fig. 4.

During stage 3 at $15 \mathrm{~km}$, (Fig. 8b), the effect of vertically upward gravity-dominated flow is clear, since the ratio $\left(\nabla_{\mathrm{Z}} \psi / \rho_{\mathrm{r}}\right)$ becomes strongly positive where water discharges to the erosion base. At $23 \mathrm{~km}$, during evolution from Stage 1 to Stage 3 in the top $1000 \mathrm{~m}$ (Fig. 8c), the ratio of vertical hydraulic gradient to relative density remains negative (indicating downward flow) but gradually increases toward zero, which reflects the gradual decrease in gravityinduced flow relative to buoyancy forces, due to the thickening confining layer.

In agreement with the findings of Mádl-Szőnyi and Tóth (2015), the simulated flow field and temperature distribution in Stage 3 confirms the convergence of fluid flow and heat toward the discharge region from different sources. The simulations presented here show, in addition, the evolution of the recent flow and heat patterns within a geological time frame.

Mádl-Szönyi and Tóth (2015) presented a conceptual model in which an interface evolves between freshwater (from an unconfined sub-basin) and basinal fluids (from a confined sub-basin) which could represent a potential dissolution zone for porosity enhancement due to the chemical differences amongst these waters.
As highlighted by Sandeep et al. (2016), strong coupling between fluid flow, heat transfer and permeability alterations can lead to transient evolution of the associated velocity and temperature fields. Identifying regions of rapid and localized permeability enhancement has economic importance with regard to hydrocarbon accumulation. However, Pollyea et al. (2015) suggest that the scale over which these processes operate is also important to determine since dissolution processes can best be interpreted based on the knowledge of physical processes operating at the relevant scale.

\section{Conclusions}

Numerical simulations have provided new insights into the processes controlling fluid flow and heat transport at the margin of unconfined and confined carbonates during their geological evolution. The simulations covered the range from fully confined conditions to the development of unconfined conditions. The Buda Thermal Karst of Hungary was used as an analogue pilot area on which to base realistic geological evolutionary stages and physical system parameters. Three scenarios of semi-synthetic models were tested to represent characteristic snapshots of the fluid evolution of the studied system.

The semi-synthetic numerical simulations of fluid flow and heat 
transport highlight the effects of paleo-recharge and confining formations, as well as the role of an evolving hydrodynamic system on heat distribution and dissipation. The first simulated stage led to the development of strong thermal convection cells which might have played an important role in the early system evolution.

The results also revealed that differential tectonic uplift led to large-scale changes in the importance of different fluid driving forces, therefore leading to changes in flow patterns and heat distribution. Uplift caused increased gravity-driven groundwater flow by the increased topographic gradients, and partly by the more intense infiltration of cold meteoric water. The temperature field was primarily free-convective-driven in early evolutionary stages, but intense fluid flow in the shallow, more permeable unconfined carbonates increasingly influenced the temperature profile. Gravity-driven flow then began to overwrite the weaker buoyancydriven flow.

Understanding changes in flow patterns over geological time scales is essential to understanding the development of permeability distributions in carbonate rocks; such insight can be provided by numerical simulations. The results should also contribute to a better understanding of hypogene karstification processes, and help identify the geothermal and hydrocarbon resource potential of deep carbonate systems.

\section{Acknowledgements}

This research was supported by the Hungarian Research Fund NK 101356 and by the Natural Sciences and Engineering Research Council of Canada (NSERC). Fruitful discussions with Dr. Andrea Mindszenty (Department of Physical and Applied Geology, ELTE, Budapest, Hungary), as well as with Dr. László Fodor (Geological, Geophysical and Space Science Research Group of the Hungarian Academy of Sciences, ELTE, Budapest, Hungary) helped place the simulations into a geological evolutionary framework, and is highly appreciated.

\section{References}

Abusaada, M., Sauter, M., 2013. Studying the flow dynamics of a karst aquifer system with an equivalent porous medium model. Groundwater 51 (4), 641-650. Alföldi, L., 1981. A budapesti geotermikus áramlási rendszer modellje [Model of the geothermal flow system in Budapest]. Hidrológiai Közlöny 61 (9), 397-403.

Alföldi, L., Bélteky, L., Böcker, T., Horváth, J., Korim, K., Liebe, P., Rémi, R., 1968 Budapest Hévizei (Thermal Waters of Budapest), VITUKI (Budapest).

Alföldi, L., Kapolyi, L., 2007. Bányászati Karsztvízszintsüllyesztés a Dunántúliközéphegységben [Mining-dewatering in the Transdanubian Range]. Geography Institute of Hungarian Academy of Sciences, Budapest.

Bear, J., 1972. Dynamics of Fluids in Porous Media (New York).

Bredehoeft, J.D. and Norton, D.L., 1990. Press, N.A. (ed), Washington, D.C, 170.

Cardenas, M.B., Jiang, X.W., 2010. Groundwater flow, transport, and residence times through topography-driven basins with exponentially decreasing permeability and porosity. Water Resour. Res. 46 (11).

Deming, D., 2002. Introduction to Hydrogeology. McGraw-Hill College, New York.

Domenico, P., Schwartz, F., 1990. Physical and Chemical Hydrogeology. Wiley, New York.

Ehrenberg, S., Nadeau, P., 2005. Sandstone vs. carbonate petroleum reservoirs: global perspective on porosity-depth and porosity-permeability relationships. AAPG Bull. 89 (4), 435-445.

Erhardt, I., Ötvös, V., Czauner, B., Erõss, A., Simon, S., Mádl-Szõnyi, J., 2013. In: MádlSzőnyi, J., Eröss, A., Mindszenty, A., Tóth, A. (Eds.), Hydraulic Evaluation of the Flow Systems of Buda Thermal Karst, Budapest, Hungary (Budapest, Hungary).

Eröss, A., 2010. Characterization of Fluids and Evaluation of Their Effects on Karst Development at the Rózsadomb and Gellért Hill, Buda Thermal Karst, Hungary. PhD Dissertation. Eötvös Loránd University, Budapest.

Erőss, A., Csoma, É., Mádl-Szőnyi, J., Sasowsky, I., Feazel, C., Mylorie, J., Palmer, A. Palmer, M., 2008. The Effects of Mixed Hydrothermal and Meteoric Fluids on Karst Reservoir Development, Buda Thermal Karst, Hungary. Karst Waters Institute, Special Publication, pp. 57-63.

Eröss, A., Mádl-Szőnyi, J., Surbeck, H., Horváth, Á., Goldscheider, N., Csoma, A.É. 2012. Radionuclides as natural tracers for the characterization of fluids in regional discharge areas, Buda Thermal Karst, Hungary. J. Hydrol. 426, 124-137.

Frind, E.O., 1982. Simulation of long-term transient density-dependent transport in groundwater. Adv. Water Resour. 5 (2), 73-88.
Galdenzi, S., Cocchioni, M., Morichetti, L., Amici, V., Scuri, S., 2008. Sulfidic groundwater chemistry in the Frasassi caves, Italy. J. Cave Karst Stud. 70 (2), 94-107.

Ghasemizadeh, R., Hellweger, F., Butscher, C., Padilla, I., Vesper, D., Field, M., Alshawabkeh, A., 2012. Review: groundwater flow and transport modeling of karst aquifers, with particular reference to the North Coast Limestone aquifer system of Puerto Rico. Hydrogeol. J. 20 (8), 1441-1461.

Gleeson, T., Manning, A.H., 2008. Regional groundwater flow in mountainous terrain: three-dimensional simulations of topographic and hydrogeologic controls. Water Resour. Res. 44 (10).

Goldscheider, N., Mádl-Szőnyi, J., Erőss, A., Schill, E., 2010. Review: thermal water resources in carbonate rock aquifers. Hydrogeol. J. 18 (6), 1303-1318.

Gulley, J., Martin, J., Spellman, P., Moore, P., Screaton, E., 2014. Influence of partial confinement and Holocene river formation on groundwater flow and dissolution in the Florida carbonate platform. Hydrol. Process. 28 (3), 705-717.

Haas, J., 1988. Upper triassic carbonate platform evolution in the Transdanubian Mid-Mountains. Acta Geol. Hung. 31 (3-4), 299-312.

Haitjema, H.M., Mitchell-Bruker, S., 2005. Are water tables a subdued replica of the topography? Groundwater 43 (6), 781-786.

Horváth, F., Dövényi, P., Szalay, A., Royden, L., 1988. Subsidence, thermal and maturation history of the Great Hungarian plain. Pannon. Basin, AAPG Mem. 45, 355-372.

Ingebritsen, S.E., Sanford, W.E., 1999. Groundwater in Geologic Processes. Cambridge University Press.

Jiang, X.W., Wan, L., Wang, X.S., Ge, S., Liu, J., 2009. Effect of exponential decay in hydraulic conductivity with depth on regional groundwater flow. Geophys. Res. Lett. 36 (24).

Kiraly, L., 1975. Rapport sur l'état actuel des connaissances dans le domaine des caractères physiques des roches karstiques [Report on the current state of knowledge in the field of physical characters of karstic rocks]. Hydrogeol. Karstic Terrains 3, 53-67.

Klimchouk, A., 2009. Morphogenesis of hypogenic caves. Geomorphology 106 (1), $100-117$.

Lapcevic, P., Novakowski, K., Sudicky, E., 1999. Groundwater flow and solute transport in fractured media, Chapter 17. In: Delleur, J.W. (Ed.), The Handbook of Groundwater Engineering, pp. 17-39.

Lenkey, L., Dövényi, P., Horváth, F., Cloetingh, S., 2002. Geothermics of the Pannonian Basin and its Bearing on the Neotectonics, pp. 29-40.

Loáiciga, H., Maidment, D., Valdes, J., 2000. Climate-change impacts in a regional karst aquifer, Texas, USA. J. Hydrol. 227 (1), 173-194.

Martinecz, A.J.M.-S., Havril, T., Molson, J., Simon, S., 2014. Numerical interpretation of groundwater flow in the Buda thermal karst, Hungary. In: Kukurić, N. Stevanović, Z., Krešić, N. (Eds.), GRAFOKOMERC AD Trebinje and DIKTAS Project (Protection and Sustainable Use of the Dinaric Karst Transboundary Aquifer System), Trebinje (Bosnia \& Herzegovina), Dubrovnik (Croatia).

Milota, K., Kovacs, A., Galicz, Z., 1995. Petroleum potential of the North Hungarian oligocene sediments. Pet. Geosci. 1 (1), 81-87.

Molson, J.W., Frind, E.O., 2015. HEATFLOW - SMOKER Version 7.0-density-dependent Flow and Advective-dispersive Transport of Thermal Energy, Mass or Residence Time in Three-dimensional Porous or Discretely-fractured Porous Media. Université Laval, Quebec, QC, Canada.

Molson, J.W., Frind, E.O., Palmer, C.D., 1992. Thermal energy storage in an unconfined aquifer: 2. Model development, validation, and application. Water Resour. Res. 28 (10), 2857-2867.

Mádl-Szőnyi, J., Pulay, E., Tóth, Á., Bodor, P., 2015. Regional underpressure: a factor of uncertainty in the geothermal exploration of deep carbonates, Gödöllö Region, Hungary. Environ. Earth Sci. 74 (12), 7523-7538.

Mádl-Szőnyi, J., Tóth, Á., 2015. Basin-scale conceptual groundwater flow model for an unconfined and confined thick carbonate region. Hydrogeol. J. 23 (7), 1359-1380.

Palmer, A., Palmer, M., 2000. Speleogenesis of the Black Hills Maze Caves, South Dakota, USA. Speleogenesis. Evolution of Karst Aquifers. National Speleological Society, Huntsville, pp. 274-281.

Pollyea, R.M., Van Dusen, E.W., Fischer, M.P., 2015. Topographically driven fluid flow within orogenic wedges: effects of taper angle and depth-dependent permeability. Geosphere 11 (5), 1427-1437.

Poros, Z., Mindszenty, A., Molnár, F., Pironon, J., Győri, O., Ronchi, P., Szekeres, Z., 2012. Imprints of hydrocarbon-bearing basinal fluids on a karst system: mineralogical and fluid inclusion studies from the Buda Hills, Hungary. Int. J. Earth Sci. 101 (2), 429-452.

Rman, N., Tóth, G., 2011. Hydrogeological Conceptual Model. Geological Survey of Slovenia and Geological Institute of Hungary.

Rodríguez, L., Vives, L., Gomez, A., 2013. Conceptual and numerical modeling approach of the Guarani aquifer system. Hydrol. Earth Syst. Sci. 17 (1), 295-314.

Ruszkiczay-Rüdiger, Z., Fodor, L., Horváth, E., 2006. Neotectonic and landscape evolution of the Gödöllö Hills, central Pannonian Basin, Hungary. Geolines 20, $116-118$.

Ruszkiczay-Rüdiger, Z., Fodor, L.I., Horváth, E., 2007. Neotectonics and quaternary landscape evolution of the Gödöllö Hills, central Pannonian Basin, Hungary. Glob. Planet. Change 58 (1), 181-196.

Sandeep, V., Chaudhuri, A., Kelkar, S., 2016. Permeability and flow field evolution due to dissolution of calcite in a 3-D porous rock under geothermal gradient and through-flow. Transp. Porous Media 1-14.

Sauter, M., 1992. Quantification and Forecasting of Regional Groundwater Flow and Transport in a Karst Aquifer (Gallusquelle, Malm, SW. Germany) (Tübingen).

Scanlon, B.R., Mace, R.E., Barrett, M.E., Smith, B., 2003. Can we simulate regional

Please cite this article in press as: Havril, T., et al., Evolution of fluid flow and heat distribution over geological time scales at the margin of unconfined and confined carbonate sequences - A numerical investigation based on the Buda Thermal Karst analogue, Marine and Petroleum Geology (2016), http://dx.doi.org/10.1016/j.marpetgeo.2016.10.001 
groundwater flow in a karst system using equivalent porous media models? Case study, Barton Springs Edwards aquifer, USA. J. Hydrol. 276 (1), 137-158.

Schmid, G., Braess, D., 1988. In: Kinzelbach, W. (Ed.), Groundwater Flow and Quality Modelling. Springer, pp. 173-188.

Teutsch, G., Sauter, M., 1991. Groundwater Modeling in Karst Terranes: Scale Effects, Data Acquisition and Field Validation. National Ground Water Association, Nashville, TN, pp. 17-35.

Turcotte, D., Schubert, G., 1982. Geodynamics: Applications of Continuum Mechanics to Geological Problems. John Wiley, New York.

Tóth, J., 2009. Gravitational Systems of Groundwater Flow: Theory, Evaluation,
Utilization. Cambridge University Press.

Wang, J. Jin, M., Jia, B., Kang, F., 2015. Hydrochemical characteristics and geothermometry applications of thermal groundwater in northern Jinan, Shandong, China. Geothermics 57, 185-195.

Weast, R., 1980. Handbook of Chemistry and Physics. CRC Press Inc., Boca Raton, Fla. Wellman, T.P., Poeter, E.P., 2006. Evaluating uncertainty in predicting spatially variable representative elementary scales in fractured aquifers, with application to Turkey Creek Basin, Colorado. Water Resour. Res. 42 (8).

Zsigmondy, V., 1878. A Városligeti Artézi Kút Budapesten (The Artesian Well of Városliget, Budapest). Légrády Testvérek, Budapest.

Please cite this article in press as: Havril, T., et al., Evolution of fluid flow and heat distribution over geological time scales at the margin of unconfined and confined carbonate sequences - A numerical investigation based on the Buda Thermal Karst analogue, Marine and Petroleum Geology (2016), http://dx.doi.org/10.1016/j.marpetgeo.2016.10.001 